\title{
Utilisation of different types of coal fly ash in the production of ceramic tiles
}

\author{
N. U. KOCKAL* \\ *Akdeniz University, Department of Civil Engineering, Antalya, Turkey
}

\begin{abstract}
The influence of varying proportions of different types of fly ash (used in place of feldspar) and different sintering temperatures on the sintered properties of ceramic tile bodies was evaluated. The results indicated that sintering ceramic tiles with a high fly ash content at a high temperature caused a decrease in the properties because of bloating. The ceramic samples containing a higher amount of fly ash that were sintered at low temperature exhibited lower water absorption, larger shrinkage and strength because of the densification observed also in microstructural investigation.
\end{abstract}

Keywords: Sintering; Microstructure; Mechanical properties; Tiles.

Utilización de diferentes tipos de cenizas volantes de carbón en la producción de baldosas cerámicas

Se ha evaluado la influencia de la proporción de diferentes tipos de cenizas volantes (en lugar de feldespato) y diferentes temperaturas de sinterización en las propiedades de soportes cerámicos. Los resultados indicaron que las composiciones con un alto contenido de cenizas volantes provocaron una disminución en las propiedades de las piczas cocidas a alta temperatura como consecuencia del hinchamiento. Las composiciones con una mayor cantidad de cenizas sinterizadas a baja temperatura mostraron una menor absorción de agua, mayor contracción y resistencia mecánica debido a la densificación como también se observó en la investigación microestructural.

Palabras clave: Sinterización, Microestructura, Propiedades mecánicas; Baldosas cerámicas.

\section{INTRODUCTION}

Thermal power plants generate large amounts of coal fly ash worldwide and only a small proportion is used in applications such as road construction and the fabrication of concrete, cement and other building materials. Fly ash leads to problems with disposal and to environmental damage by causing air and water pollution on a large scale. Approximately 15 million tonnes of fly ash is produced annually in Turkey [1], while a very small amount of it is being used in the construction industry.

Over the last few years, considerable progress has been made in the development of new building materials from wastes. However, very little research has focused on ways to improve the properties of ceramic tiles by using fly ash. The physical and mechanical properties of ceramics are important parameters for defining their use and applications. The properties of ceramic tiles with different types of by-products incorporated have been investigated in recent years [2-6]. Recent researches have studied the synthesis and characterization of ceramic bricks and tiles from coal fly ash and incinerated paper mill sludge [7], metal finishing wastes [8], municipal solid waste incineration ash [9], marine dredging spoils, incinerated sewage sludge and steelworks slag [10], iron ore tailing [11] and granite sawing wastes [12]. Influence of fly ash granulometry and pentasodium triphosphate addition on dry pressed ceramic tiles based on fly ash-clay body was investigated by Sokolar and Smetanova [13]. A study of the sintering of fly ash and its mixture with low alkali pyrophyllite in the presence of sodium hexa meta phosphate, a complex activator of sintering, for the purpose of wall tile manufacturing was conducted [14]. The environmental and economic feasibility of ceramic tiles was also studied by Bovea et al [15]. Some researchers evaluated the effects of firing temperatures on bending strength and Vickers hardness in fired ceramic roofing tiles from kaolinite and illite-carbonate clay materials [16].

The suitability of fly ash for use in the ceramic tile manufacturing industry is difficult to estimate because of the different physico-chemical factors. Therefore, in this study, different types of fly ash were used to investigate their physical and mechanical behaviour and the microstructural changes after sintering by taking their as-received characteristics into account. Feldspar was replaced with two different types of fly ash in different proportions between 0 and $20 \mathrm{wt} . \%$ while keeping the other raw materials the same. The effect of these different types of fly ash sintered at different temperatures on the properties of the ceramic tile body was studied by measuring their linear shrinkage, water absorption and flexural strength. The thermal expansion behaviour, phase composition and morphology of the tiles were also examined for the microstructural evaluation. 


\section{MATERIALS AND METHODS}

\subsection{Materials used in ceramic production}

The fly ash samples used in this study were provided by Tuncbilek (TFA) and Seyitomer (SFA) power plants, Kutahya, Turkey. Table 1 and Figure 1 show the chemical compositions and the particle size distribution, respectively, of the as-received fly ash samples.

These fly ash samples were classified according to the ASTM classification [17] as Class F, which accounts for the low content of calcium oxide and the high content of $\mathrm{SiO}_{2}+\mathrm{Al}_{2} \mathrm{O}_{3}$ $+\mathrm{Fe}_{2} \mathrm{O}_{3}$ (Table 2).

The other raw materials used were feldspar, three different clays and silica sand. Feldspar was replaced with increasing amounts of fly ash. The values for the other ingredients were kept constant: silica sand 5\%, clay A $49 \%$ and clay B (magnesium-rich clay) 3\%. The water content was $50 \mathrm{wt} . \%$ of the total solid materials. The details of the batch compositions are given in Table 3 . The raw materials were provided by a tile company so that a batch of tile could be made with the recipe for the standard mixture (control), which was designated STN.

\subsection{Production of ceramic tiles}

The raw material mixtures for the production of the test samples were wet-milled. It is well known that the sintering rate is related to the grain size of the ingredients. Therefore, the milling duration was adjusted to obtain a 4.5-5.5 wt.\% residue of grains on a $0.063 \mathrm{~mm}$ sieve.

After milling, the mixtures were dried in an oven at $150{ }^{\circ} \mathrm{C}$. After the drying process, the mixtures were cooled, ground, sieved and humidified at $5.5 \mathrm{wt} . \%$ of the mixture by spraying. The humidified mixture was sieved once again to avoid agglomeration due to moisture. The mixture was thus prepared and left in a plastic bag for 12 hours. Testing samples with a green body size of $100.4 \mathrm{~mm} \times 100.4 \mathrm{~mm} \times 6$ $\mathrm{mm}$ were uniaxially pressed at $40 \mathrm{MPa}$ for ten seconds. Prior to the sintering process, the pressed body was dried at 110 ${ }^{\circ} \mathrm{C}$ until at a constant mass was obtained for two successive measurements made at an interval of $2 \mathrm{~h}$.

The green bodies were then sintered at temperatures of 1130 and $1190{ }^{\circ} \mathrm{C}$ with a 6-minute soaking time at the maximum temperatures. The sintering process of the tiles was performed in two different industrial roller furnaces

TABle 1. ChemicAl COMPOSITION OF THE WASTES AND COMMERCIAL RAW MATERIAL USED.

\begin{tabular}{|c|c|c|c|c|c|c|c|c|c|c|c|c|c|}
\hline \multirow{2}{*}{$\begin{array}{l}\text { Raw } \\
\text { Materials }\end{array}$} & \multicolumn{13}{|c|}{ Weight percent } \\
\hline & $\mathrm{LOI}^{\mathrm{a}}$ & $\mathrm{Na}_{2} \mathrm{O}$ & $\mathrm{MgO}$ & $\mathrm{Al}_{2} \mathrm{O}_{3}$ & $\mathrm{SiO}_{2}$ & $\mathrm{P}_{2} \mathrm{O}_{5}$ & $\mathrm{SO}_{3}$ & $\mathrm{~K}_{2} \mathrm{O}$ & $\mathrm{CaO}$ & $\mathrm{TiO}_{2}$ & $\mathrm{Cr}_{2} \mathrm{O}_{3}$ & $\mathrm{MnO}$ & $\mathrm{Fe}_{2} \mathrm{O}_{3}$ \\
\hline TFA & 0.77 & 0.10 & 3.57 & 18.11 & 60.19 & 0.26 & 1.41 & 1.61 & 2.63 & 0.91 & 0.11 & 0.14 & 10.28 \\
\hline SFA & 3.00 & 0.66 & 4.76 & 14.06 & 52.12 & 0.14 & 3.02 & 2.03 & 6.41 & 0.75 & 0.09 & 0.11 & 12.64 \\
\hline Clay A & 6.15 & 0.15 & 0.37 & 22.07 & 64.32 & - & 0.27 & 3.04 & 0.26 & 1.22 & - & - & 2.10 \\
\hline Clay B & 45.51 & 0.14 & 41.16 & 1.22 & 8.48 & - & 0.50 & 0.08 & 2.22 & 0.02 & - & - & 0.62 \\
\hline Feldspar & 1.40 & 5.56 & 0.23 & 18.09 & 71.63 & - & - & 1.19 & 0.41 & 0.34 & - & - & 1.08 \\
\hline Silica sand & 1.59 & 0.11 & 0.03 & 5.40 & 90.67 & - & - & 1.29 & 0.08 & 0.33 & - & - & 0.42 \\
\hline STN & 5.04 & 2.88 & 1.12 & 19.10 & 66.88 & - & 0.12 & 2.11 & 0.32 & 0.80 & - & - & 1.55 \\
\hline
\end{tabular}

${ }^{\text {a }}$ Loss on ignition.

TABLE 2. CHEMICAL PROPERTIES OF FLY ASHES USED AND SPECIFICATIONS.

\begin{tabular}{|c|c|c|c|}
\hline Properties & TFA & SFA & ASTMC 618 (Class-F) \\
\hline $\mathrm{SiO}_{2}+\mathrm{Al}_{2} \mathrm{O}_{3}+\mathrm{Fe}_{2} \mathrm{O}_{3}(\%)$ & 88.58 & 78.82 & 70 (min) \\
\hline $\mathrm{MgO}(\%)$ & 3.57 & 4.76 & $5(\max )$ \\
\hline $\mathrm{CaO}(\%)$ & 2.63 & 6.41 & 10 (max) \\
\hline $\mathrm{SO}_{3}(\%)$ & 1.41 & 3.02 & $5(\max )$ \\
\hline Loss on ignition (\%) & 0.77 & 3.00 & $6(\max )$ \\
\hline
\end{tabular}

TABLE 3. THE COMPOSITION OF INVESTIGATED BODIES AND THEIR NOTATIONS (\%).

\begin{tabular}{|c|c|c|c|c|c|c|c|c|c|}
\hline \multirow{2}{*}{ Materials } & \multicolumn{9}{|c|}{ Sample Codes } \\
\hline & STN & T5 & T10 & T15 & T20 & S5 & S10 & S15 & $\mathrm{S} 20$ \\
\hline Feldspar & 43 & 38 & 33 & 28 & 23 & 43 & 38 & 33 & 28 \\
\hline Fly ash (Seyitomer) & - & - & - & - & - & 5 & 10 & 15 & 20 \\
\hline
\end{tabular}


for each sintering temperature (Figure 2). The sintering proceeded as follows: for temperatures of 1130 and $1190{ }^{\circ} \mathrm{C}$; the time required to reach the peak temperatures was 15 and 18 minutes, respectively, and the duration of cooling was 10 minutes for all of the temperatures.

\subsection{Tests and analysis performed on the raw materials and the ceramic bodies}

The particle size distribution data for the as-received fly ash and the standard sample shown in Figure 1 were analysed by laser diffraction using a Mastersizer 2000 (Malvern Instruments, UK). Both fly ash samples, which had similar particle size distributions, were much coarser than the standard sample. It can be seen that the as-received SFA and TFA fly ash had an average particle size $\left(\mathrm{d}_{50}\right)$ of $26.3 \mu \mathrm{m}$ and $30.2 \mu \mathrm{m}$, respectively. It was also revealed that the standard sample was finely ground, with approximately $95 \%$ of the particles having sizes $\left(\mathrm{d}_{95}\right)$ of less than $100 \mu \mathrm{m}$.

The flexural strength of the sintered specimens was evaluated using a three-point flexural strength test on a universal testing machine (Gabrielli, Italy). The average values of the flexural strength were calculated by the following equation:

$$
\sigma_{\mathrm{f}}=3 \times \mathrm{FxL} / 2 \times \mathrm{bxh}^{2}
$$

where $\mathrm{F}$ is the breaking load $(\mathrm{kg}), \mathrm{L}$ is the span length, $\mathrm{b}$ is the tile width $(\mathrm{mm})$ and $\mathrm{h}$ is the tile thickness (mm).

The water absorption (\%) of the produced materials was determined by the boiling water method using the procedure outlined in the ASTM C 20 [18].

$$
\mathrm{W}(\%)=\left(\mathrm{W}_{\mathrm{s}}-\mathrm{W}_{\mathrm{d}} / \mathrm{W}_{\mathrm{s}}\right) \times 100
$$

where $\mathrm{W}_{\mathrm{s}}$ is the weight of the specimen in saturated surface dry conditions and $\mathrm{W}_{\mathrm{d}}$ is the weight of an oven-dried specimen.

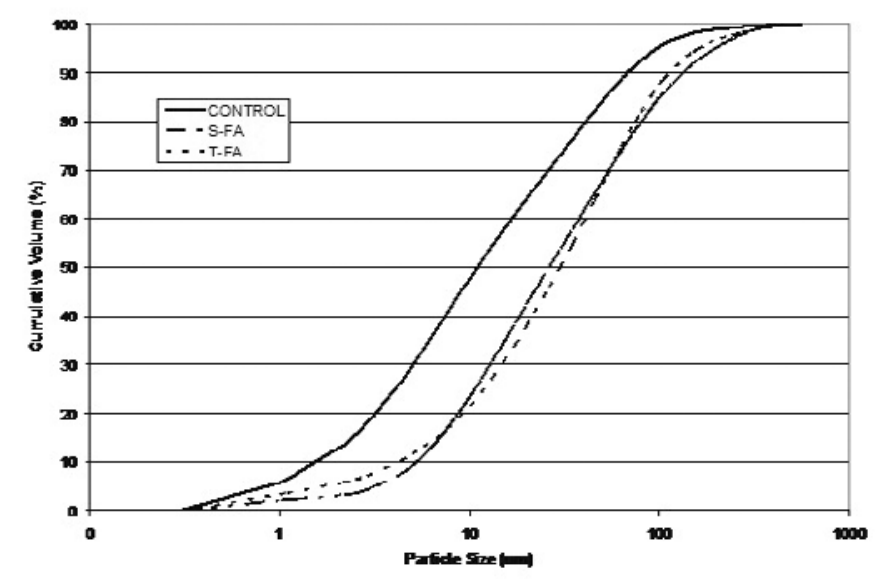

Figure 1. Granulometry of as-received fly ashes and milled standard mixture.
The sample shrinkage was determined from the differences in the green and fired sample sizes. The $\%$ linear shrinkage was evaluated by the formula given below:

$$
\mathrm{L}(\%)=\left(\mathrm{L}_{1}-\mathrm{L}_{2} / \mathrm{L}_{1}\right) \times 100
$$

where $\mathrm{L}_{1}$ and $\mathrm{L}_{2}$ are the accurately measured length of the green and sintered tile samples, respectively.

The tests mentioned above were performed on three samples from each batch.

The colour measurements of the sintered bodies were done with a Minolta Chroma Meter (CR-300, Japan). The values are expressed as L (lightness factor) and chromaticity coordinates a (red) and b (yellow).

The linear thermal expansion coefficients of the industrially fired bodies ( $50 \mathrm{~mm} \times 6 \mathrm{~mm} \times 6 \mathrm{~mm}$ ) were determined using a Netzsch thermal dilatometer (DIL 402 PC, Germany) at a heating rate of $10^{\circ} \mathrm{C} / \mathrm{min}$ to $650{ }^{\circ} \mathrm{C}$.

The crystalline phases present in the sintered ceramic samples were analysed using X-ray diffraction (XRD). Data were collected using a Rigaku diffractometer (Rint 2200, Japan) equipped with a copper rotating anode, $\mathrm{Cu} \mathrm{K} \alpha$ radiation with a secondary graphite crystal monochromator and a scintillation detector.

The morphology of the phases formed on the fractured surface of the sintered samples was examined using scanning electron microscopy (SEM) (Zeiss $50 \mathrm{VP}$ ) combined with energy dispersive X-ray spectroscopy (Oxford Instrument Inca Energy).

\section{RESULTS AND DISCUSSION}

The use of coal fly ashes from two different thermal power plants in the manufacturing of ceramic tiles affected the final properties of these products. The results of the evaluated properties, namely, linear shrinkage, water absorption, flexural strength and colour measurements, are presented in Table 4.

At $1130{ }^{\circ} \mathrm{C}$, the samples retained their structural integrity, whereas at $1190^{\circ} \mathrm{C}$, the samples with $20 \%$ TFA, and especially those with $20 \%$ SFA, bloated completely because of the evolving gas and lost their structure entirely because of the presence of a high level of $\mathrm{CaSO}_{4}$ in the as-received fly ash. The content of calcium oxide increased with the incorporation of larger amounts of fly ash, promoting sample expansion and increasing water absorption and strength reduction. Therefore, samples with defective bodies after sintering were not further tested. Also, black core increased gradually as the

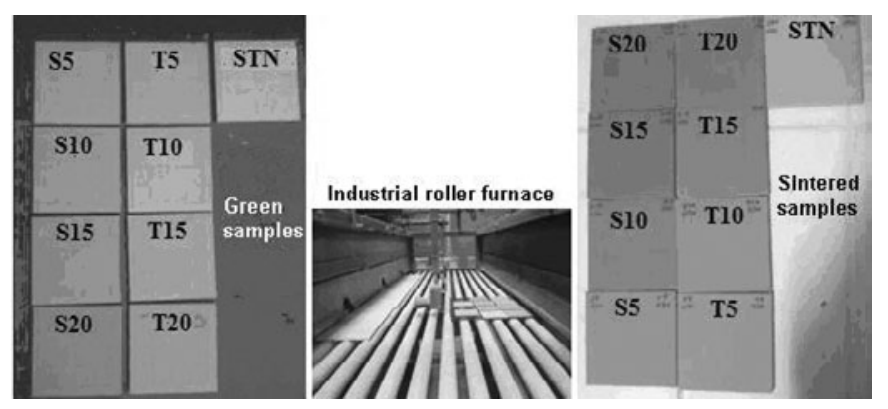

Figure 2. Production of ceramic tiles. 

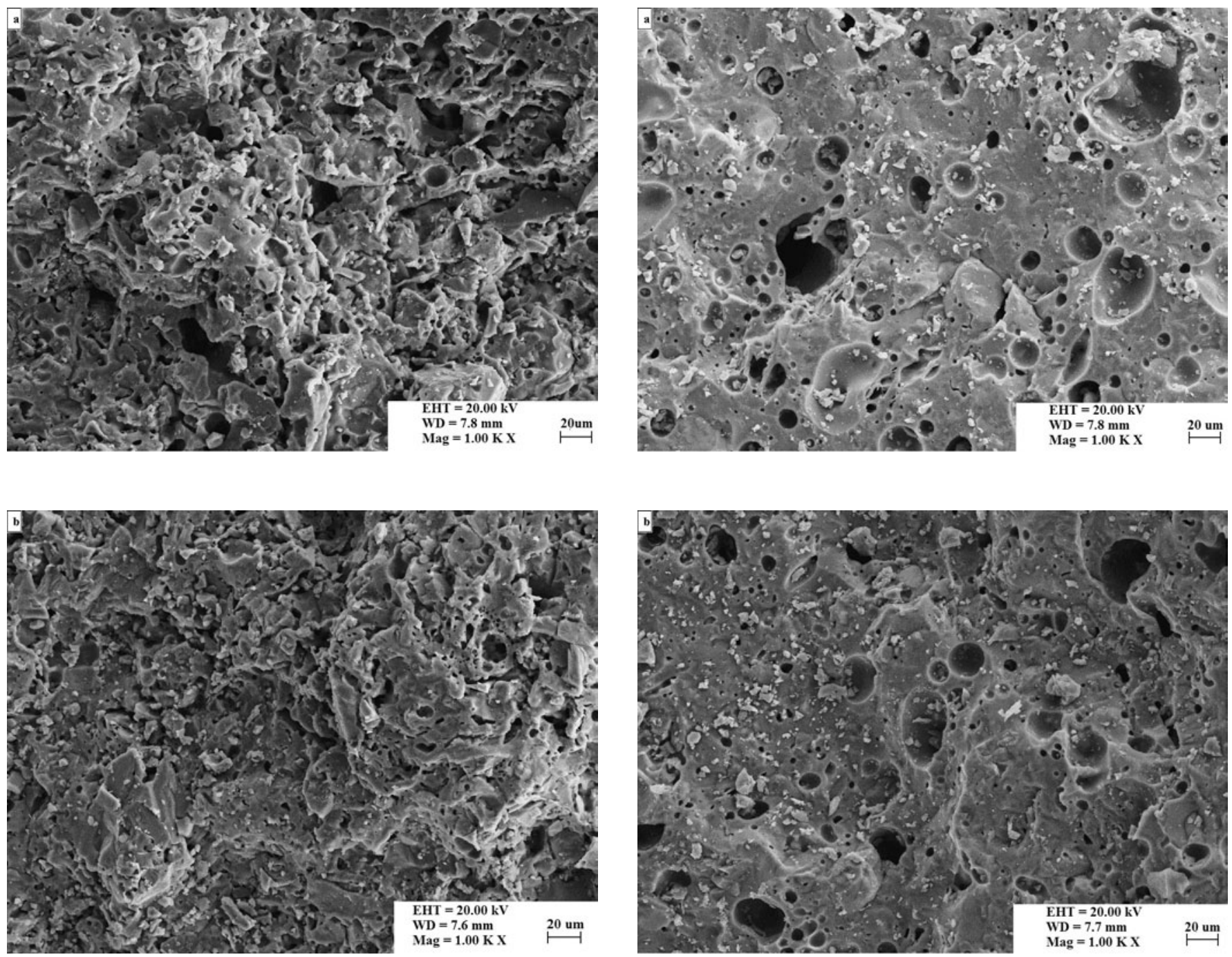

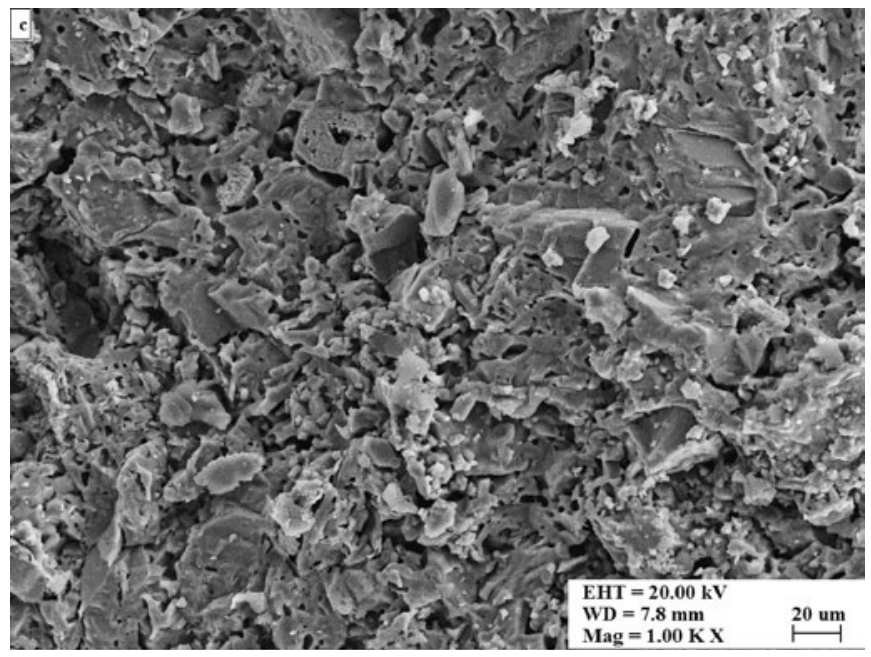

Figure 3. Microstructures of fractured surface of tiles after sintering at $1130{ }^{\circ} \mathrm{C}$ (a) $10 \%$ SFA (b) $10 \%$ TFA and (c) STN.

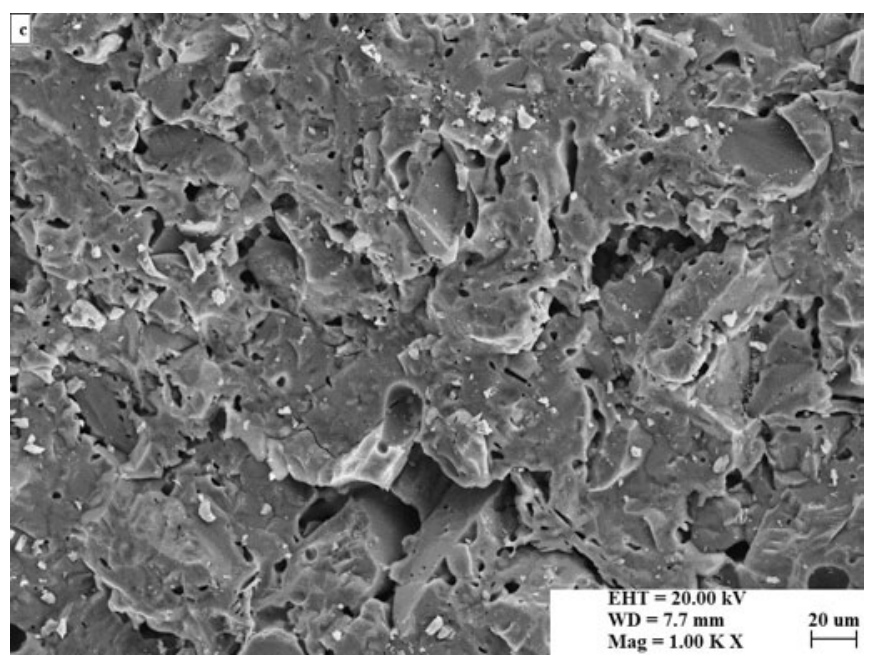

Figure 4. Microstructures of fractured surface of tiles after sintering at $1190^{\circ} \mathrm{C}$ (a) $10 \%$ SFA (b) $10 \%$ TFA and (c) STN. 
ash content increased in all samples containing SFA sintered at the high temperature. This behaviour can be attributed to the high heating rate, which resulted in less complete burning of the residual carbon. Carbonaceous and organic matter content can be measured by the loss on ignition (LOI). As can be seen in Table 1, SFA had higher LOI value than TFA. Carbonaceous matter contents of two fly ashes were also determined according to ASTM D 6316 [19] and the contents for SFA and TFA were $2.64 \%$ and $0.71 \%$, respectively. The presence of excessive carbon in fly ash is regarded as a serious issue in the developed world due to its effect on plant efficiency and the possibility of landfill taxes related to the nature of the ash [20]. Variable and unacceptable carbon contents adversely affect ash utilisation. This black core occurrence also indicated that during rapid sintering, the fly ash was not fully vitrified, nor did it crystallise out. It reacted as a filler in the framework of the sintered ceramic body. The surface of the samples sintered at the low temperature had a very smooth texture. At $1130{ }^{\circ} \mathrm{C}$, a significant difference in their structure was not seen; their colour did get darker with increasing amounts of fly ash.

The sintered colour of the samples is expressed in terms of the $\mathrm{L}$, a and $\mathrm{b}$ values (Table 4). All samples with fly ash exhibited lower $\mathrm{L}$ values than the standard tile. The lightness in the colour of the samples decreased with an increase in the fly ash content because of the presence of $\mathrm{Fe}_{2} \mathrm{O}_{3}$ and unburned carbon. For ceramic tiles containing SFA, the $\mathrm{L}$ value was lower compared with tiles containing TFA because of the higher amounts of iron oxide and unburned impurities (Table 1). Also, the amount of $\mathrm{Fe}_{2} \mathrm{O}_{3}$ present in both materials was responsible for the red colour of all of the sintered samples, which got darker as the sintering temperature increased. However, tiles containing SFA had a darker reddish coloration than those containing TFA at $1130{ }^{\circ} \mathrm{C}$. This reddish colouration turned brown at $1190{ }^{\circ} \mathrm{C}$.

As can be seen in Table 4, the water absorption values of the sintered products decreased with increasing amounts of TFA and SFA, especially at $1130{ }^{\circ} \mathrm{C}$. In addition, there was a corresponding increase in the linear shrinkage values at 1130 ${ }^{\circ} \mathrm{C}$ and a decrease at higher temperatures. This behaviour was mainly due to the fluxing action of the fly ash. This fact can be used as an advantage in order to reduce the maximum sintering temperature or lower the tile soaking time at vitrification temperatures. The reduced shrinkage observed by sintering at $1190{ }^{\circ} \mathrm{C}$ indicated that samples were beginning to bloat or warp.

The reduction in open, water-accessible porosity that occurred with increased sintering temperatures was also observed in another investigation [21]. Samples sintered at $1190{ }^{\circ} \mathrm{C}$ were nearly impermeable. The occurrence of open porosity in the sintered samples could be favoured by different causes, such as entrapped air in the ceramic slurry, formation of voids during the different drying steps, gases released in the thermal decomposition of carbonates and sulphates or even liberation of gases dissolved in quartz particles [22]. As the sintering temperature increases, the capillary pressure due to the surface tension of the liquid phase tends to approach the particles, which in turn changes the porosity from open to closed porosity, which is formed by larger, isolated, spherical

TABLE 4. SINTERED PROPERTIES OF CERAMIC TILES.

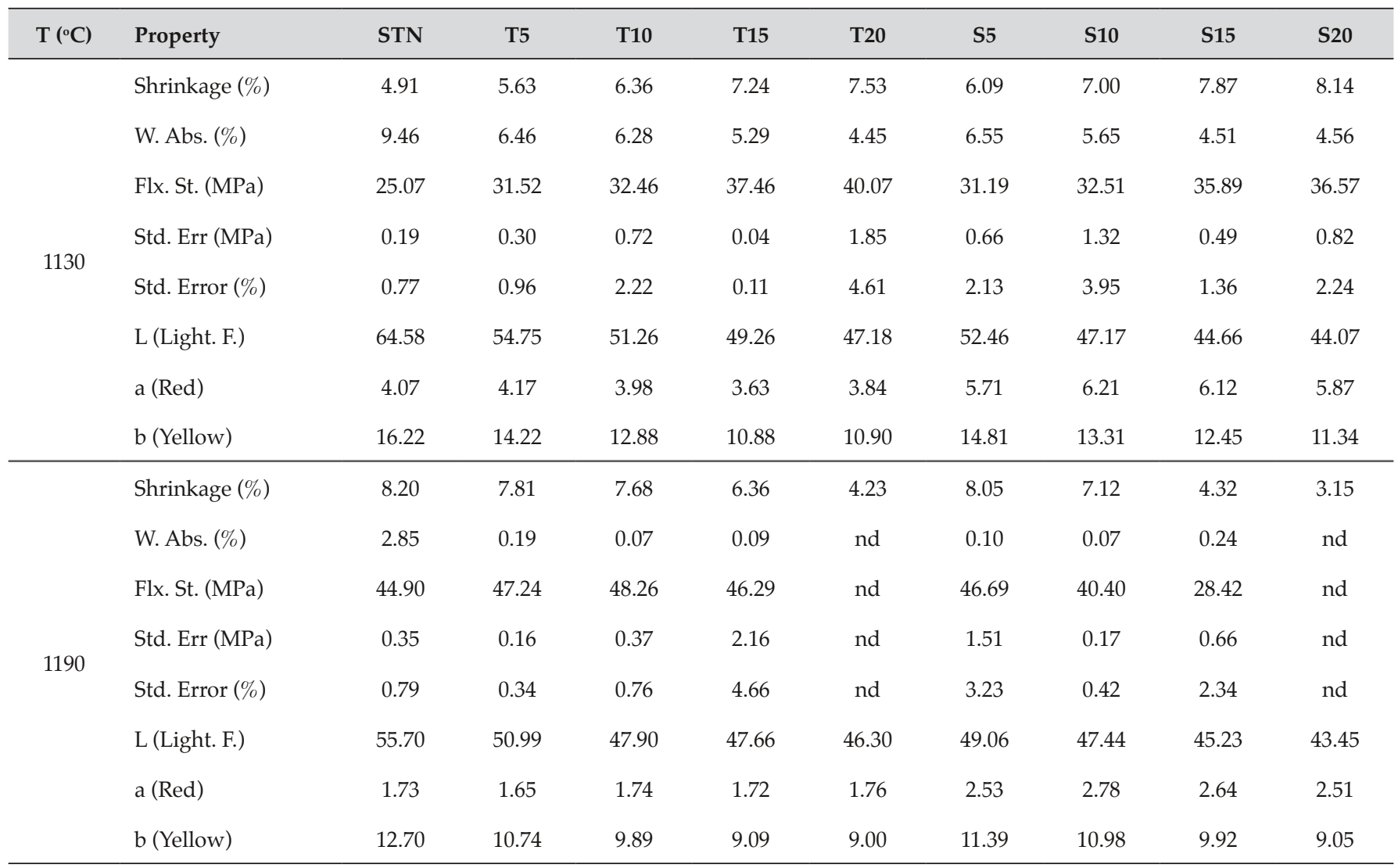

$\mathrm{nd}=$ not determined 


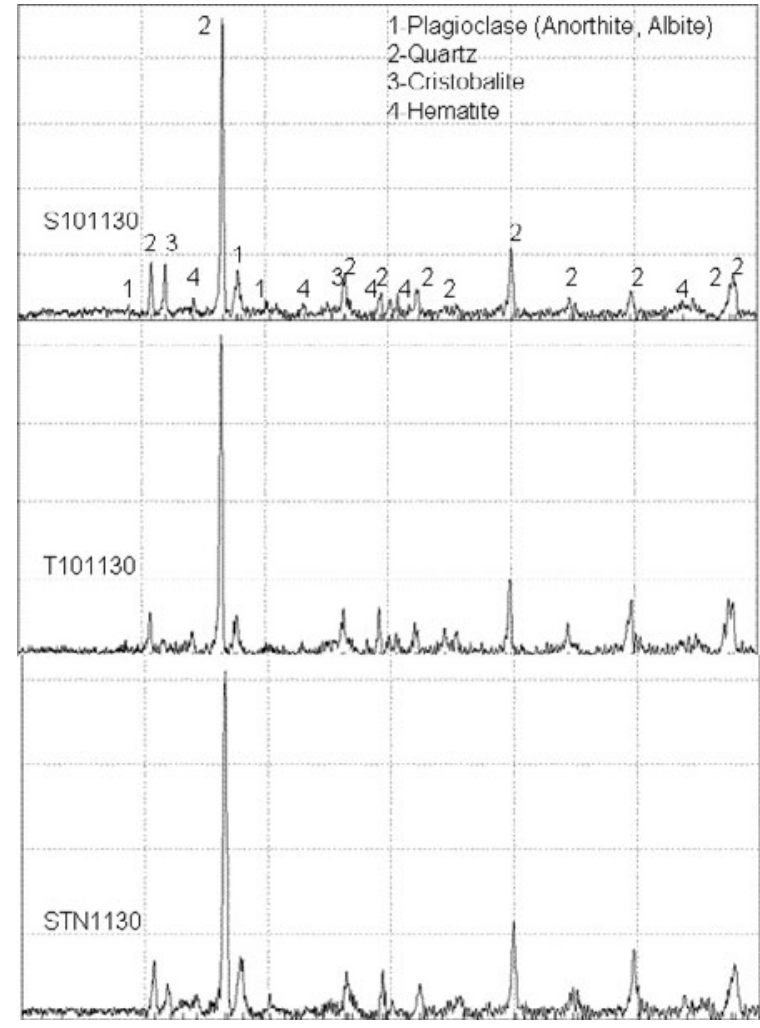

Figure 5. X-ray diffractogram for ceramic tiles sintered at $1130^{\circ} \mathrm{C}$.

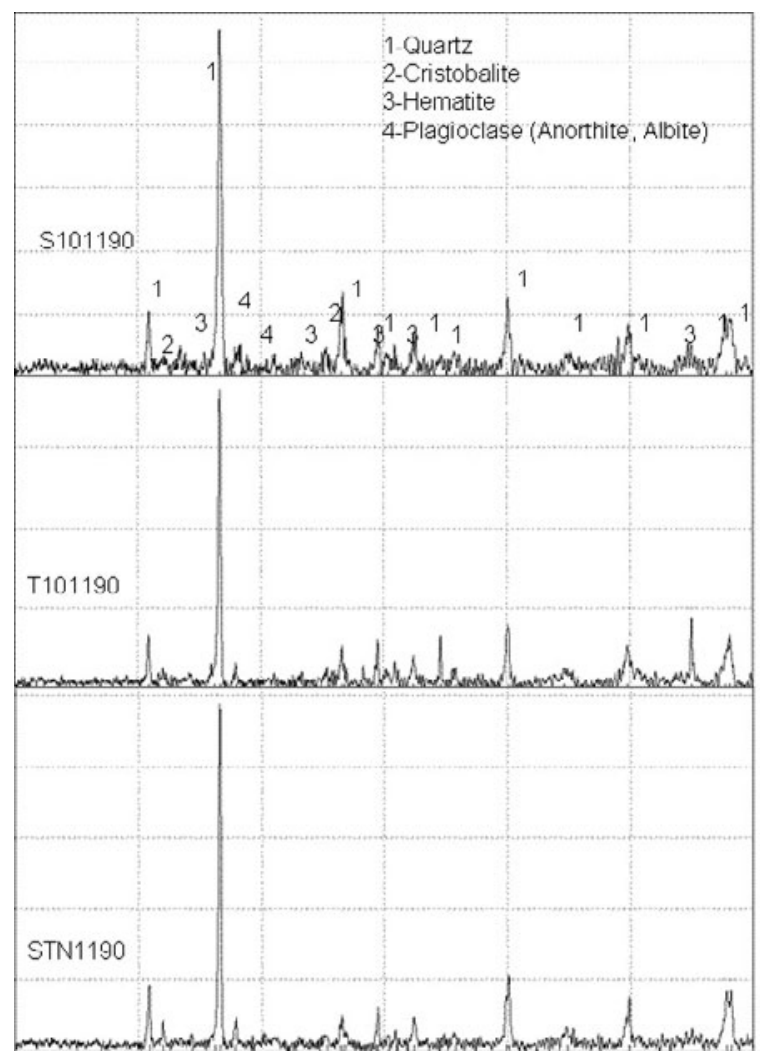

Figure 6. X-ray diffractogram for ceramic tiles sintered at $1190{ }^{\circ} \mathrm{C}$. pores. The bloating at high temperatures did not introduce significant amounts of open connected porosity to the ceramic material formed. It was determined that the samples with SFA that were sintered at $1130{ }^{\circ} \mathrm{C}$ exhibited higher shrinkage and slightly lower water absorption values than the samples with TFA, which is in agreement with the chemical composition of SFA having a high amount of sodium, potassium, magnesium and calcium oxides acting as fluxing agents compared with TFA. These alkaline elements improved the development of the viscous liquid phase during sintering. Thus, these oxides behaving as sintering promoters began to melt together with silica and filled the pores, causing a reduction in porosity in the case of sintering at $1130{ }^{\circ} \mathrm{C}$ (Figure 3). Furthermore, the proper viscosity could be determined from the chemical compositions of the raw materials used [23, 24]. Generally, the total $\mathrm{CaO}$ and $\mathrm{MgO}$ contents account for the sudden change in the viscosity of the raw materials at high temperatures. The addition of fly ash to the ceramic slurry initiated the formation of a low viscosity melt at a low temperature by providing an easier mass transport mechanism. In addition to the sintering temperature reduction, the milling duration also decreased. The reason for the decreasing duration of milling was decreases in the feldspar contents in the batches. Sintering at temperatures above $1130{ }^{\circ} \mathrm{C}$ caused samples to exhibit a bloating effect associated with increased porosity because of the pressure of the entrapped gas inside the closed pores, which tended to expand the pores (Figure 4). A further increase in the ash content led to deformations and defects in the tiles because of extreme bloating.

It was found that lower water absorption and higher shrinkage values contributed to the higher flexural strength values. Three-point flexural strength results are given in Table 4. The results clearly indicate that the strength of samples sintered at $1130{ }^{\circ} \mathrm{C}$ increased with increasing fly ash content. Additionally, samples exhibited higher strength values as the sintering temperature increased, regardless of the tile body composition. The highest value of the flexural strength $(48.26 \mathrm{MPa})$ was obtained for the sample made using $10 \%$ TFA and sintered at $1190{ }^{\circ} \mathrm{C}$. The strength clearly increased with increasing TFA and SFA content up to $15 \%$ and $10 \%$, respectively, at the sintering temperature of 1190 ${ }^{\circ} \mathrm{C}$. At this temperature, SFA showed lower strength than TFA because of the larger pores that occurred after sintering (Figure 4). Different behaviours were observed between body compositions containing TFA and SFA at high temperatures:

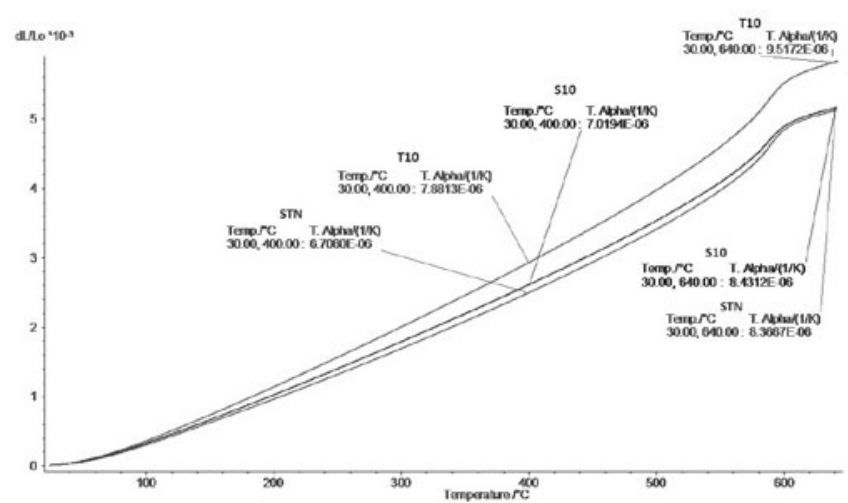

Figure 7. Thermal expansion curves of the selected tile bodies sintered at $1130{ }^{\circ} \mathrm{C}$ 
TFA warped like a hump because of the amount of glassy phase that was formed, whereas SFA exhibited blistering because of the entrapped gasses and excessive bloating during sintering.

Figures 5 and 6 show the XRD patterns of ceramic tile compositions with 10\% TFA, 10\% SFA and without fly ash that were sintered at 1130 and $1190{ }^{\circ} \mathrm{C}$, respectively. The mineral phases of the tiles were identified as quartz, plagioclase, cristobalite and hematite. It was observed that all compositions contained quartz as a major phase. Cristobalite could be formed from crystallisation of the amorphous silica. At low temperatures, released silica did not dissolve in the melt and apparently partially transformed to cristobalite. Significant phase differences were not detected among the compositions. However, albite peaks existing in the tiles without fly ash disappeared, while anorthite peaks emerged in the compositions with fly ash. Anorthite is the most thermodynamically stable product among the calcium aluminosilicates, and its formation is probably related to the reaction between the calcium oxide from fly ash and from the decomposition of calcite with metakaolinite formed in clay sintering and the quartz introduced with clays. The formation of anorthite in the sintering of the fly ashcontaining ceramic mixture occurs both via the diffusion mechanism in the solid phase with the formation of primary fine-crystalline aluminosilicate and via the crystallisation of secondary long-prismatic crystals from the saturated solution [25]. The diffusion of calcium and aluminium ions is the basis for the solid-phase reaction between the fly ash and the amorphous argillaceous residue. Hardening associated with solid particle aggregation took place because of anorthite crystal fusion in the peaks characteristic for the interplanar distances of anorthite from 0.375 to $0.138 \mathrm{~nm}$. Peak intensities corresponding to the plagioclase decreased at $1190{ }^{\circ} \mathrm{C}$. The glassy phase formation that was detected was related to plagioclase grains dissolving in the matrix because of the higher sintering temperature.

The thermal expansion coefficient is an important property of a ceramic body. Figures 7 and 8 show the linear thermal expansion values of the selected tile bodies. It is generally known that ceramic materials having lower coefficients of thermal expansion exhibit higher resistance to thermal shock, despite their low ductility. The thermal expansion values of the tiles with fly ash that were sintered at $1190^{\circ} \mathrm{C}$ were slightly lower than those of the standard tile. Between the two types

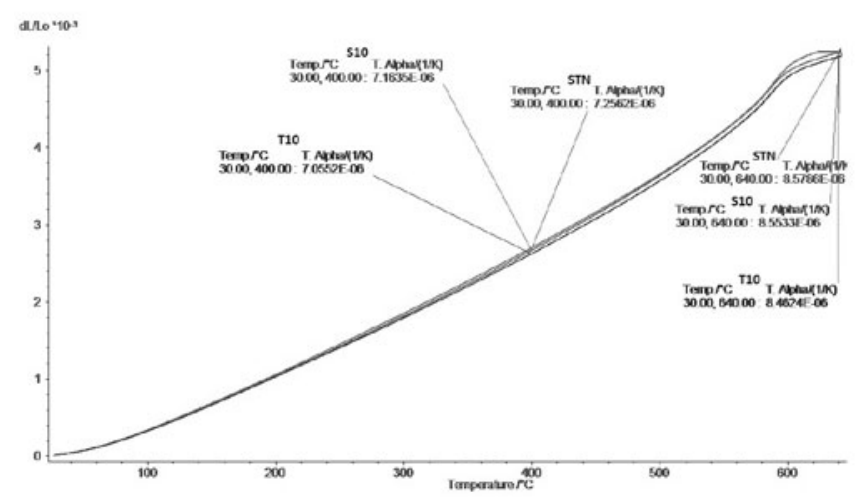

Figure 8 . Thermal expansion curves of the selected tile bodies sintered at $1190{ }^{\circ} \mathrm{C}$ of fly ash, the tile containing TFA showed higher thermal expansion than that containing SFA. This can be attributed to the higher amount of glassy phase in the tiles with TFA and SFA, which dissolved free quartz during melting. In contrast, tiles with fly ash that were sintered at $1130{ }^{\circ} \mathrm{C}$ expanded more than the standard tile did.

\section{CONCLUSIONS}

The study reported here served to indicate how the structural and microstructural properties of ceramic tiles could be improved through the use of different types of fly ash and different sintering temperatures.

The results showed that incorporating fly ash into the ceramic slurry produced a ceramic body with properties such as shrinkage, water absorption and strength that were comparable with those of commercial ceramic materials that are used for floor and wall tiles. Therefore, use of fly ash in the fabrication of ceramics could provide not only superior properties for the ceramic tiles but also a pathway to recycle a waste whose disposal problems increase year after year.

The main inconvenience was the occurrence of black core in samples with SFA at high temperature because of the high heating rate. Moreover, samples sintered at a high temperature exhibited excessive surface defects because of gas evolution, bloating and warping when the amount of fly ash was increased. Thus, in future research, the ceramic body composition could be varied and the heating process could be adjusted to overcome these negative characteristics.

\section{REFERENCES}

1. N. Degirmenci, A. Okucu, A. Turabi, Application of phosphogypsum in soil stabilization, Build. Environ., 42, 3393-3398 (2007).

2. A. Zimmer, C. P. Bergmann, Fly ash of mineral coal as ceramic tiles raw material, Waste Manage., 27, 59-68 (2007).

3. N. Y. Mostafa, A. A. Shaltout, M. S. Abdel-Aal, A. El-maghraby, Sintering mechanism of blast furnace slag-kaolin ceramics, Mater. Design, 31, 36773682 (2010)

4. H. Yang, S. Wu, J. Hu, Z. Wang, R. Wang, H. He, Influence of nano-ZRO additive on the bending strength and fracture toughness of fluoro-silicic mica glass-ceramics, Mater. Design, 32, 1590-1593 (2011).

5. F. Quereda, E. Sánchez, J. García-Ten, A. Gozalbo, V. Beltrán, J. Sánchez, J. Sales, Uso del carbonato sódico como ligante en composiciones de baldosas cerámicas, Bol. Soc. Esp. Ceram. V., 49, 4, 327-334 (2010).

6. M. P. Gómez, M. F. Gazulla, E. Zumaquero, M. Orduña, Utilización de técnicas acopladas de análisis térmico TG-DSC-QMSFTIR en la caracterización de arcillas y composiciones cerámicas utilizadas en la fabricación de baldosas cerámicas, Bol. Soc. Esp. Ceram. V., 46, 5, 259-266 (2007).

7. E. Furlani, S. Bruckner, D. Minichelli, S. Maschio, Synthesis and characterization of ceramics from coal fly ash and incinerated paper mill sludge, Ceram. Int., 34, 2137-2142 (2008).

8. M. R. Little, V. Adell, A. R. Boccaccini, C. R. Cheeseman, Production of novel ceramic materials from coal fly ash and metal finishing wastes, Resour. Conserv. Recycl., 52, 1329-1335 (2008).

9. Z. Haiying, Z. Youcai, Q. Jingyu, Study on use of MSWI fly ash in ceramic tile, J. Hazard. Mater., 141, 106-114 (2007).

10. D. Baruzzo, D. Minichelli, S. Bruckner, L. Fedrizzi, A. Bachiorrini, S Maschio, Possible production of ceramic tiles from marine dredging spoils alone and mixed with other waste materials, J. Hazard. Mater., B134, 202-210 (2006).

11. S. K. Das, S. Kumar, P. Ramachandrarao, Exploitation of iron ore tailing for the development of ceramic tiles, Waste Manage., 20, 725-729 (2000).

12. R. R. Menezes, H. S. Ferreira, G. A. Neves, H. L. Lira, H. C. Ferreira, Use of granite sawing wastes in the production of ceramic bricks and tiles, J. Eur. Ceram. Soc., 25, 1149-1158 (2005). 
13. R. Sokolar, L. Smetanova, Dry pressed ceramic tiles based on fly ash-clay body: influence of fly ash granulometry and pentasodium triphosphate addition, Ceram. Int., 36, 215-221 (2010).

14. N. Chandra, P. Sharma, G. L. Pashkov, E. N. Voskresenskaya, S. S. Amritphale, N. S. Baghel, Coal fly ash utilization: low temperature sintering of wall tiles, Waste Manage., 28, 1993-2002 (2008).

15. M. D. Bovea, E. Diaz-Albo, A. Gallardo, F. J. Colomer, J. Serrano, Environmental performance of ceramic tiles: improvement proposals, Mater. Design, 31, 35-41 (2010)

16. L. Sidjanin, J. Ranogajec, D. Rajnovic, E. Molnar, Influence of firing temperature on mechanical properties on roofing tiles, Mater. Design, 28, 941-947 (2007).

17. ASTM C 618, Standard specification for coal fly ash and raw or calcined natural pozzolan for use in concrete, Annual Book of ASTM Standards, 1998.

18. ASTM C 20, Standard test methods for apparent porosity, water absorption, apparent specific gravity, and bulk density of burned refractory brick and shapes by boiling water, Annual Book of ASTM Standards, 2000.

19. ASTM D 6316, Standard test method for determination of total, combustible and carbonate carbon in solid residues from coal and coke, Annual Book of ASTM Standards, 2000 .
20. P. Hamley, E. Lester, A. Thompson, M. Cloke, M. Poliakoff, The removal of carbon from fly ash using supercritical water oxidation, International Ash Utilization Symposium, University of Kentucky, paper\#85, 2001.

21. N. U. Kockal, T. Ozturan, Characteristics of lightweight fly ash aggregates produced with different binders and heat treatments, Cem. Concr. Compos., 33, 61-67 (2011).

22. M. Romero, A. Andres, R. Alonso, J. Viguri, J. M. Rincon, Sintering behaviour of ceramic bodies from contaminated marine sediments, Ceram. Int., 34, 1917-1924 (2008).

23. M. Aineto, A. Acosta, J. M. Rincon, M. Romero, Thermal expansion of slag and fly ash from coal gasification in IGCC power plant, Fuel, 85, 2352-2358 (2006).

24. V. Adell, C. R. Cheeseman, M. Ferraris, M. Salvo, F. Smeacetto, A. R. Boccaccini, characterising the sintering behaviour of pulverised fuel ash using heating stage microscopy, Mater. Character., 58, 980-988 (2007).

25. A. K. Abdurakhmanov, A. M. Eminov, G. N. Maslennikova, Stages of ceramic structure formation in the presence of additives, Glass Ceram., 57, 354-356 (2000). 